\title{
Immunoquantitative Measurement of Soybean Aeroallergen Emissions
}

\author{
María-Jesús Cruz and Susana Gómez-Ollés \\ Respiratory Department. Hospital Vall d'Hebron. Barcelona \\ Spain
}

\section{Introduction}

Environmental allergen exposure plays an important role in the development and expression of asthma and allergy. To study allergen exposure, it is necessary to actually measure allergen levels. Direct measurement is also needed to assess what levels lead to sensitisation or provoke symptoms in already sensitised subjects, and evaluate the efficacy of allergy reduction strategies (1). The measurement of aeroallergens plays a key role in asthma prevention.

Both the epidemiological studies and the studies on specific IgE to soybean carried out following the asthma epidemics in Barcelona attributed their cause to the unloading of soybean in the harbour (2-3). The environmental intervention in September 1987 with the installation of bag filters in a silo led to a decrease in airborne soybean concentrations and the subsequent disappearance of the epidemics (4). The 1,555 $\mathrm{U} / \mathrm{m}^{3}$ level of soybean allergen detected during a determined asthma epidemic day (5-6) was substantially higher than the highest value $\left(165 \mathrm{U} / \mathrm{m}^{3}\right)$ recorded in 22 unloading days after the interventions (4). These data show that the measurement of soybean aeroallergen levels in harbours loading and unloading soybean is of increasing importance in controlling the efficiency of the environmental interventions in order to prevent new asthma outbreaks in these areas.

In the evaluation of occupational asthma, measurement of the causal agent in the air at worksites is a necessary additional link in the chain of evidence that a suspected allergen is the cause of the pathology. Such measurements are particularly useful when the allergen is unknown, the environment of interest has never before been assessed, and control measures have to be considered. Knowledge of the concentration at work also allows correlation between exposure of workers and an inhalation challenge test in the laboratory, which is performed in individual patients to confirm that the suspected allergenic material that evoked the IgE antibody can actually cause an asthmatic response (7). Thus, it is of great interest to monitor soybean dust levels indoors.

\section{Soybean aeroallergens}

\subsection{Epidemic asthma allergens}

Investigation of the epidemics in the city of Barcelona revealed that the outbreaks were caused by soybean dust generated by unloading of soybeans in the harbour on days when the wind carried the soybean dust over the city $(2-3,8)$. Rodrigo et al. (8) demonstrated that during an epidemic the serum of patients with asthma reacted specifically to an acidic, low- 
molecular mass $(\mathrm{LMM})$ protein $(<14 \mathrm{kDa})$ located principally in hulls and dust of soybeans unloaded in the harbour. Two proteins located in soybean hulls were later shown to be the main allergens responsible for this asthma epidemic (9). Both proteins are isoallergens (Gly $\mathrm{m} 1 \mathrm{a}$ and Gly $\mathrm{m} 1 \mathrm{~b}$ ) with molecular weights of 7.0 and $7.5 \mathrm{kDa}$, respectively, and are highly homologous with the hydrophobic soybean protein (HSP) described by Odani et al. (10).

\subsection{Occupational asthma allergens}

Exposure to soybean dust and flour has been reported to cause occupational allergic asthma in persons working in a variety of occupations, such farmers, mill workers, soybean handlers and bakers (11-19).

It has been established that the allergens responsible for occupational asthma in bakers exposed to soy flour are not the same as those involved in soy dust-induced asthma epidemics, and the proteins causing both these conditions may differ from those involved in cases of adverse reactions following oral ingestion of soy (19). The low-molecular weight (LMW) soybean hull proteins $(8,20)$, Gly $\mathrm{m} 1(9,21)$ and Gly $\mathrm{m} 2(22)$ have been identified as the main allergens that cause the asthma outbreaks, while allergens responsible for soybean flour-induced occupational asthma would be mainly high-molecular weight (HMW) proteins $(17,19)$. Soy hull components may, however, also have been involved in occupational asthma reported in animal feed manufacturers (23). Thus, 'soy aeroallergen exposure' might vary markedly between worksites.

In 1988 a study was performed to characterize the allergens involved in a food-processing worker's IgE-mediated response to soybean flour (15). Nine proteins were recognised, with molecular weights ranging from 54.5 to $14.9 \mathrm{kDa}(15)$. Reactivity to soybean flour was also observed in a study performed by Alvarez et al (24) in 9 of 21 cereal workers. Therefore, the allergens involved in occupational asthma may differ from the causative agents in the Barcelona epidemics.

\section{Methods for immunoquantitative measurement of soybean aeroallergen}

For monitoring aeroallergens it is indispensable to have simple and reliable techniques. Morphologically identifiable allergenic particles such as pollen grains can be quantified by appropriate air sampling techniques and counting microscopically. Viable particles such as mould spores can be cultured quantitatively. Chemical assays for LMW substances such as diisocyanates have been invaluable in monitoring the environment for efficacy of control measures assigned to reduce exposure (25). But many allergens are amorphous, non-viable particles that cannot be quantified by these methods. Thus, the current means for objectively quantifying airborne allergens levels is air sampling on filter, elution of the allergens from the filter, and measurement of allergen concentration in the eluate by specific immunoassays.

Several different immunological methods have been used to measure occupational and environmental allergens, with the Radio Allergo Sorbent Test (RAST) and Enzyme Linked Immunoabsorvent Assay (ELISA)-inhibition being the most used. However, ELISA has replaced the RAST in many laboratories, as it offers comparable sensitivity without the problems of disposal and the short half-life associated with radioactive materials. Immunoassays measure allergen levels in samples by using antibodies directed against the allergens. The antibodies may be derived from pooled sera from sensitised patients or from experimentally sensitised animals. The latter can be either polyclonal antibodies that recognise a range of epitopes, or monoclonal antibodies, consisting of one clone of a specific antibody. Sandwich or inhibition assay set-ups can be utilised (1). 
Specific human IgE is theoretically the ideal antibody, since, by definition, it only detects the allergen to be measured (26). However, an obvious disadvantage of assays using human IgE antibody is the limited availability of suitable sera and the occupational health risk associated with the handling of human blood samples. Availability is even poorer because of the low absolute titres; at times nearly undiluted sera must be used for the IgE inhibition assays. Moreover, IgE inhibition methods are frequently considered semiquantitative assays with potential long-term reproducibility problems because of the use of heterogeneous antibody pools (27). Furthermore, testing by different laboratories using their own serum pools may be subject to inter-laboratory and possibly inter-batch differences in allergen recognition profiles (28). This makes comparison of absolute measurements of airborne allergens among different studies difficult (29). Due to those limitations other assays have been developed.

\subsection{Monitoring soy aeroallergens causing epidemic asthma}

To monitor soy aeroallergens in the city of Barcelona, samples are obtained by large-volume automated air samplers containing glass microfiber filters with a $1 \mu \mathrm{m}$ pore size of. In October 1986, two samplers were installed in highly populated areas of the city where many epidemic cases had been identified (5). Further studies were centred on results obtained from the municipal atmospheric contamination control station located in the port authority customs building. This station was closest to the soy processing plants and to neighbourhoods with the largest number of affected patients (30). Allergens were extracted from the filters and immunochemically assayed. Measurements from sampling filters yield a 24 hour average.

Some immunoassays have been described for quantifying airborne levels of the LMW soy allergens (20,31-32). A human IgE ELISA-inhibition method is currently used for daily monitoring of the soy hull LMW (SHLMW) aeroallergens in the city of Barcelona (31) (Figure 1A). The amplified ELISA inhibition method use as antigen and reference preparation a SHLMM extract which contains proteins with a molecular weight lower than $10 \mathrm{kDa}$ and as primary antibody a pool of human sera. This method is useful for soybean monitoring but, has the drawbacks of using human antibodies and being an inhibition method.

Because the widespread use of human sera in these assays is complicated by their limited availability and a relatively low sensitivity, other assays have been developed, such as the monoclonal antibody based method to quantify Gly m 1 (32). However, the high specificity of a monoclonal antibody-based ELISA - depending on the recognition of a single epitope could also be a disadvantage if in some soy dust mixtures the epitope is masked and the actual allergen exposure level is thus underestimated (33). Therefore recently was also developed a polyclonal rabbit IgG-based assay for soy hull antigens. Gomez-Olles et al (34) describes an 'amplified ELISA', that combines a high sensitivity with reasonably high specificity while avoiding the risk of false-negatives associated with the use of monoclonal antibodies (Figure 1B). There are positive advantages of using polyclonals, e.g. cheaper and easier, the polyclonal method is less disturbed by epitope losses, several allergens may be present that can be detected and polyclonal methods can be made very sensitive.

\subsection{Monitoring soy aeroallergens causing occupational asthma}

Epidemiologic studies suggest that in addition to genetic and other factors related to individual susceptibility, one determinant of the prevalence of occupational asthma is the level of exposure to a workplace sensitizer (35).

Since the introduction of immunochemical techniques, a considerable number of exposure studies have been performed in a wide range of occupational settings. Allergen exposure has been assessed for enzymes such as papain in the meat processing industry, fungal $\alpha$ - 
amylase in the baking industry, egg protein, pig and cow urinary and dander proteins in agriculture, wheat allergens, and rat and mouse urinary allergens (26). The first reports of soy allergy were occupation-related and occurred in soybean mill workers (11).

To evaluate differences in quality and quantity of soy aeroallergens among different worksites and assess the suitability of different immunoassays to measure workplace soy aeroallergens levels, a large series of airborne samples were collected in three European countries in soy plants, animal feed industries and in pig farms (36). Samples were either analysed for airborne soy allergen by five ELISAs with different specificity and/or sensitivity. Comparison of allergen levels measured by the different ELISAs showed a very strong correlation between several of the methods. Nevertheless, some differences were found between some of these methods. These differences can be attributed in part to differences in the specificities of antibodies and allergen standards, as found in other studies where differences in antibody specificities accounted for up to 800-fold differences (37).

Reported soy aeroallergen levels also depended strongly on the sampling site. In addition, the relative ranking of exposure levels in various work environments depended in the ELISA applied, and this could also be ascribed to the different specificities of the methods. Thus, the data strongly suggest that airborne samples from different work environments with 'soy exposure' may contain 'soy dust' with quite different composition. For example, soy hull antigens are more commonly found at sites where whole soybeans are unloaded and stored, such as at the harbour silos in Barcelona $(8,9)$, whereas in a work environment where processed soybean and flours are used, such as feed and food industries, the airborne soy proteins maybe mainly soy flour-derived. Differences in soy allergen composition of airborne samples and differences in ELISA antibody specificity might also explain the very low correlations between some of the assays.

Thus, no unambiguous answer can be given to the question regarding the optimal procedure for assessment of airborne soy allergen exposure. In addition to the sensitivity, specificity and reproducibility of the assays and the availability of reagents, the work environment that is going to be evaluated should be considered.

\section{A) Inhibition ELISA using specific human IgE}
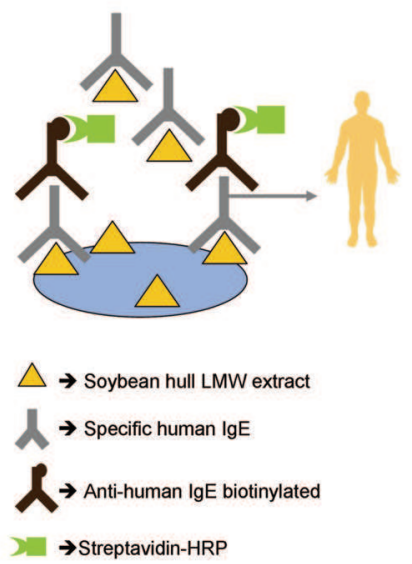

\section{B) Amplified Sandwich ELISA using specific rabbit polyclonal $\lg G$}
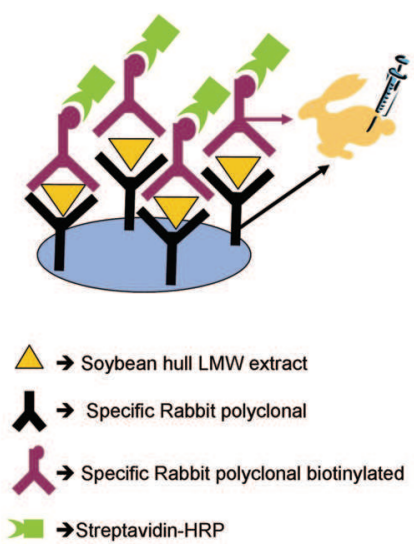

Fig. 1. 


\section{References}

[1] Renstrom A. Exposure to airborne allergens: A review of sampling methods. J Environ Monit 2002;4(5):619-22.

[2] Anto JM, Sunyer J, Rodriguez-Roisin R, Suarez-Cervera M, Vazquez L. Community outbreaks of asthma associated with inhalation of soybean dust. Toxicoepidemiological committee. N Engl J Med 1989;320(17):1097-102.

[3] Sunyer J, Anto JM, Rodrigo MJ, Morell F. Case-control study of serum immunoglobulin-E antibodies reactive with soybena in epidemic asthma. Lancet 1989;1:179-82.

[4] Anto JM, Sunyer J, Reed CE, Sabria J, Martinez F, Morell F, et al. Preventing asthma epidemics due to soybeans by dust-control measures. $N$ Engl J Med 1993;329(24):1760-3.

[5] Aceves M, Grimalt JO, Sunyer J, Anto JM, Reed CE. Identification of soybean dust as an epidemic asthma agent in urban areas by molecular marker and RAST analysis of aerosols. J Allergy Clin Immunol 1991;88(1):124-34.

[6] Soriano JB, Anto JM, Plasencia A, and the Barcelona Soybean-Asthma Group. Repeaters count: A sentinel method for asthma outbreaks. Thorax 1995;50(10):1101-3.

[7] Swanson MC, Heederik D. Quantification of Bio-Active Protein Aerosols. In: Bernstein IL, Chan-Yeung M, Malo JL, Bernstein DI eds. Asthma in the workplace, 3rd edition. New York: Taylor and Francis, 2006: 275-96.

[8] Rodrigo MJ, Morell F, Helm RM, Swanson M, Greife A, Anto JM, et al. Identification and partial characterization of the soybean-dust allergens involved in the Barcelona asthma epidemic. J Allergy Clin Immunol 1990;85(4):778-84.

[9] Gonzalez R, Varela J, Carreira J, Polo F. Soybean hydrophobic protein and soybean hull allergy. Lancet 1995;346:48-9.

[10] Odani S, Koide T, Ono T, Seto Y, Tanaka T. Soybean hydrophobic protein: Isolation, partial characterization and the complete primary structure. Eur J Biochem 1987;162(3):485-91.

[11] Duke WW. Soybean as a possible important source of allergy. Allergy 1934;5:300-2.

[12] Bush RK, Cohen M. Immediate and late onset asthma from occupational exposure to soybean dust. Clin Allergy 1977;7(4):369-73.

[13] Bourgeois M. Asthme sévère par inhalation de poussière de soja. Rev Fr Allergol 1984;24(4):209-10.

[14] Pepys J. Occupational allergic lung disease caused by organic agents. J Allergy Clin Immunol 1986;78(5 pt 2):1058-62.

[15] Bush RK, Schroeckenstein D, Meier-Davis S, Balmes J, Rempel D. Soybean flour asthma: Detection of allergens by immunoblotting. J Allergy Clin Immunol 1988;82(2):251-5.

[16] Baur X, Sauer W, Weiss W. Baking additives as new allergens in baker's asthma. Respiration 1988;54(1):70-2.

[17] Baur X, Pau M, Czuppon A, Fruhmann G. Characterization of soybean allergens causing sensitization of occupationally exposed bakers. Allergy 1996;51(5):326-30.

[18] Lavaud F, Perdu D, Prevost A, Vallerand H, Cossart C, Passemard F. Baker's asthma related to soybean lecithin exposure. Allergy 1994;49(3):159-62.

[19] Quirce S, Polo F, Figueredo E, Gonzalez R, Sastre J. Occupational asthma caused by soybean flour in bakers - differences with soybean-induced epidemic asthma. Clin Exp Allergy 2000;30(6):839-46.

[20] Swanson MC, Li JT, Wentz-Murtha PE, Trudeau WL, Fernandez-Caldas E, Greife A, et al. Source of the aeroallergen of soybean dust: A low molecular mass glycopeptide from the soybean tela. J Allergy Clin Immunol 1991;87(4):783-8. 
[21] Gonzalez R, Polo F, Zapatero L, Caravaca F, Carreira J. Purification and characterization of major inhalant allergens from soybean hulls. Clin Exp Allergy 1992;22(8):748-55.

[22] Codina RM, Calderon E, Lockey RF, Fernandez-Caldas E, Rama R. Specific immunoglobulins to soybean hull allergens in soybean asthma. Chest 1997;111(1):75-80.

[23] Maggio P, Monso E, Baltasar M, Morera J. Occupational asthma caused by soybean hull: A workplace equivalent to epidemic asthma. Allergy 2003;58(4):350-1.

[24] Alvarez MJ, Tabar AI, Quirce S, Olaguibel JM, Lizaso MT, Echechipia S, et al.Diversity of allergens causing occupational asthma among cereal workers as demonstrated by exposure procedures. Clin Exp Allergy 1996;26(2):147-53.

[25] Reed CE, Swanson MC, Agarwal MK, Yunginger JW. Allergens that cause asthma. Identification and quantification. Chest 1985;87(1 Suppl):40S-4S.

[26] Heederik D, Doekes G, Nieuwenhuijsen MJ. Exposure assessment of high molecular weight sensitisers: Contribution to occupational epidemiology and disease prevention. Occup Environ Med 1999;56(11):735-41.

[27] Renstrom A, Gordon S, Larsson PH, Tee RD, Newman-Taylor AJ, Malmberg P. Comparison of a radioallergosorbent (RAST) inhibition method and a monoclonal enzyme linked immunosorbent assay (ELISA) for aeroallergen measurement. Clin Exp Allergy 1997;27(11): 1314-21.

[28] Bogdanovic J, Wouters IM, Sander I, Zahradnik E, Elms J, Rodrigo MJ, et al. Airborne exposure to wheat allergens: Optimised elution for airborne dust samples. J Environ Monit 2006;8(10):1043-8.

[29] Gordon S, Kiernan LA, Nieuwenhuijsen MJ, Cook AD, Tee RD, Newman-Taylor AJ. Measurement of exposure to mouse urinary proteins in an epidemiological study. Occup Environ Med 1997;54(2):135-40.

[30] Villalbi JR, Plasencia A, Manzanera R, Armengol R, Anto JM, Collaborative and Technical Support Groups for the study of soybean asthma in Barcelona. Epidemic soybean asthma and public health: New control systems and initial evaluation in Barcelona, 1996-98. J Epidemiol Community Health 2004;58(6):461-5.

[31] Cruz MJ, Rodrigo MJ, Anto JM, Morell F. An amplified ELISA inhibition method for the measurement of airborne soybean allergens. Int Arch Allergy Immunol 2000;122(1):42-8.

[32] Gonzalez R, Duffort O, Calabozo B, Barber D, Carreira J, Polo F. Monoclonal antibodybased method to quantify Gly $\mathrm{m} 1$. Its application to assess environmental exposure to soybean dust. Allergy 2000;55(1):59-64.

[33] Gordon S. Laboratory animal allergy: A british perspective on a global problem. ILAR J 2001;42(1):37-46.

[34] Gomez-Olles S, Cruz MJ, Renstrom A, Doekes G, Morell F, Rodrigo MJ. An amplified sandwich EIA for the measurement of soy aeroallergens. Clin Exp Allergy 2006;36(9):1176-83.

[35] Tarlo SM, Purdham J. Air sampling in occupational asthma. J Allergy Clin Immunol 2002; 109(4): 603-5.

[36] Gomez-Olles S, Cruz MJ, Bogdanovic J, Wouters IM, Doekes G, Sander I, et al. Assessment of soy aeroallergen levels in different work environments. Clin Exp Allergy 2007;37(12):1863-72.

[37] Renstrom A, Gordon S, Hollander A, Spithoven J, Larsson PH, Venables KM, et al. Comparison of methods to assess airborne rat and mouse allergen levels. II. Factors influencing antigen detection. Allergy 1999; 54(2):150-7. 


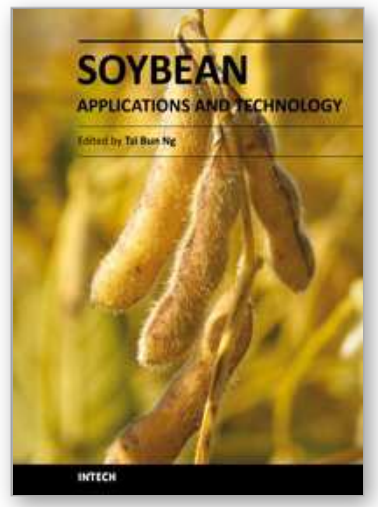

\section{Soybean - Applications and Technology \\ Edited by Prof. Tzi-Bun Ng}

ISBN 978-953-307-207-4

Hard cover, 402 pages

Publisher InTech

Published online 03, February, 2011

Published in print edition February, 2011

Soybean is an agricultural crop of tremendous economic importance. Soybean and food items derived from it form dietary components of numerous people, especially those living in the Orient. The health benefits of soybean have attracted the attention of nutritionists as well as common people.

\section{How to reference}

In order to correctly reference this scholarly work, feel free to copy and paste the following:

María-Jesús Cruz and Susana Gómez-Ollé (2011). Immunoquantitative Measurement of Soybean Aeroallergen Emissions, Soybean - Applications and Technology, Prof. Tzi-Bun Ng (Ed.), ISBN: 978-953-307207-4, InTech, Available from: http://www.intechopen.com/books/soybean-applications-andtechnology/immunoquantitative-measurement-of-soybean-aeroallergen-emissions

\section{INTECH}

open science | open minds

\section{InTech Europe}

University Campus STeP Ri

Slavka Krautzeka 83/A

51000 Rijeka, Croatia

Phone: +385 (51) 770447

Fax: +385 (51) 686166

www.intechopen.com

\section{InTech China}

Unit 405, Office Block, Hotel Equatorial Shanghai

No.65, Yan An Road (West), Shanghai, 200040, China

中国上海市延安西路65号上海国际贵都大饭店办公楼405单元

Phone: +86-21-62489820

Fax: $+86-21-62489821$ 
(C) 2011 The Author(s). Licensee IntechOpen. This chapter is distributed under the terms of the Creative Commons Attribution-NonCommercialShareAlike-3.0 License, which permits use, distribution and reproduction for non-commercial purposes, provided the original is properly cited and derivative works building on this content are distributed under the same license. 